\title{
Can nutritional aspects of Crambe abyssinica be modulated by phosphorus supply and water availability?
}

\author{
¿Pueden los aspectos nutricionales de Crambe abyssinica ser modulados \\ por la suplementación con fósforo y la disponibilidad de agua?
}

\author{
Tafarel Victor Colodetti*1, Marcelo Antonio Tomaz ${ }^{1}$, Rogério Rangel Rodrigues ${ }^{2}$, \\ Wagner Nunes Rodrigues ${ }^{1,3}$, Lima Deleon Martins ${ }^{1,4}$, Sebastião Vinícius Batista Brinate ${ }^{1}$, \\ Edvaldo Fialho dos Reis ${ }^{1}$, José Francisco Teixeira do Amaral ${ }^{1}$
}

\begin{abstract}
Phosphorus is a major limiting nutrient for crops in tropical regions. In addition, another major challenge for the future agriculture will be to maintain water levels in the soil to ensure satisfactory crop development. This study inserted in this context aimed to evaluate the conditioning caused by phosphorus fertilization and water availability in the soil over the biomass production and nutritional efficiency of plants of crambe (Crambe abyssinica Hochst). To this end, the experiment was conducted in a greenhouse, with four levels of phosphorus fertilization and three levels of water availability, along of 45 days, in order to obtain information about the production of biomass, nutritional contents, and the patterns of the nutritional efficiency of crambe plants. The results show that increasing the phosphorus supply in the soil promotes greater biomass production in crambe plants. In addition, the increase in water availability and levels of phosphorus fertilization near the recommended level promotes greater nutritional efficiencies in absorb, translocate and use the phosphorus available in the soil.
\end{abstract}

Keywords: Crambe, mineral nutrition, soil, water, oilseeds.

\section{RESUMEN}

La disponibilidad de agua y fósforo es una limitante para los cultivos en las regiones tropicales. El objetivo de este estudio fue evaluar el efecto de la fertilización fosfatada y la disponibilidad de agua en el suelo sobre la producción de biomasa y la eficiencia nutricional de las plantas de crambe (Crambe abyssinica Hochst). Las plantas fueron cultivadas en un invernadero, con cuatro niveles de fertilización de fósforo y tres niveles de disponibilidad de agua, para estudiar el comportamiento vegetativo entre emergencia y floración. Se evaluó la biomasa, contenido nutricional y patrones de eficiencia nutricional de las plantas. Los resultados muestran un aumento de biomasa al fertilizar con fósforo. Se observa un efecto sinérgico al aumentar la disponibilidad de agua y fósforo, mejorando la eficiencia en la absorción del fósforo disponible en el suelo.

Palabras clave: crambe, nutrición mineral, suelo, agua, oleaginosas.

\section{Introduction}

Crambe (Crambe abyssinica Hochst) is a species from the Brassicaceae family, originating in the Mediterranean. This oilseed plant has shown good adaptation to different climatic conditions (Souza et al., 2009); it is an excellent alternative for biodiesel production; it provides good quality oil for this purpose without compromising food production since it is grown in intercrop season. However, there is still little information about this crop, requiring scientific advances to consolidate this species in a sustainable energy matrix, prioritizing genetic improvement and optimizing agricultural inputs such as nutrients and water in the soil (Colodetti et al., 2012).

\footnotetext{
1 Centro de Ciências Agrárias e Engenharias, Universidade Federal do Espírito Santo (CCAE-UFES), Alto Universitário, S/ No, Cx Postal 16, Bairro Guararema, CEP: 29500-000, Alegre, ES, Brazil..

2 Instituto Federal de Educação, Ciência e Tecnologia do Pará (IFPA). Santarém, PA, Brazil.

3 Centro Universitário Unifacig (UNIFACIG). Manhuaçu, MG, Brazil.

4 Centro Universitário São Camilo (SÃO CAMILO). Cachoeiro de Itapemirim, ES, Brazil.

* Corresponding Author: tafarelcolodetti@hotmail.com
}

Fecha de Recepción: 3 de Junio, 2019.

Fecha de Aceptación: 26 de Diciembre, 2020. 
In tropical regions, studies for the introduction of crops must initially prioritize the limiting factors. The literature reports that phosphorus $(\mathrm{P})$ is a major limiting nutrient for crops in tropical regions (Novais et al., 2007). In addition, another major challenge for the future agriculture will be to maintain water levels in the soil to ensure satisfactory crop development (Siqueira et al., 2010). Especially considering the current scenario of growing demand for crops aiming to supply food and energy, and alterations in the rainfall patterns related to climate change, which indicate increased risk of droughts and lead to the need for studies seeking the rational use of water for agriculture purposes.

Regarding the efficient use of phosphorous, the adequate availability of this nutrient is essential for maximum development and production of oil plants such as crambe oil, since they respond to phosphorus, both in development and fruit production (Bajehbaj et al., 2009; Rogério et al., 2013; Silva et al., 2011).

Water supply associated with mineral nutrition occupies a prominent place for obtaining good yields and proper crop development. The lack of water in the soil effects the metabolism, transportation, and translocation of solutes in the plant, change turgidity of the cells of chloroplasts, opening and closing of stomata, and expansion of the root system; even a small reduction in water availability can limit the growth, development and hence crop productivity (Taiz and Zeiger, 2013).

Contextualized by this issue, this study aimed to evaluate the conditioning caused by phosphorus fertilization and water availability in the soil over the biomass production and nutritional efficiency of plants of crambe (Crambe abyssinica Hochst).

\section{Material and Methods}

\section{Experimental setup}

The experiment was conducted in a greenhouse, located in the Centro de Ciências Agrárias of the Universidade Federal do Espírito Santo (CCAUFES), in the municipality of Alegre-ES, at an altitude of $136 \mathrm{~m}$, with geographic coordinates $20^{\circ} 45^{\prime} \mathrm{S}$ and $41^{\circ} 30^{\prime} \mathrm{W}$.

The experiment followed a factorial scheme $4 \times 3$, with four levels of phosphorus fertilization and three levels of water availability, in a completely randomized design. Four replications were used, and the experimental plot was composed of one plant per pot.

\section{Phosphorus fertilization}

The soil used to fill the pots was classified as Oxisol, collected to a depth of 10 to $30 \mathrm{~cm}$. It was chemically analyzed, presenting low phosphorus content $\left(5.96 \mathrm{mg} \mathrm{dm}^{-3}\right)$, confirming its viability for studies with phosphorus fertilization. The fertility of the soil, considering all other nutrients, was corrected following the recommendations for essays in controlled environments (Novais et al., 1991).

The four levels of fertilization with $\mathrm{P}_{2} \mathrm{O}_{5}$ were established to provide $20 \%, 60 \%, 100 \%$, and $130 \%$ of the recommendation, giving, respectively, 0.06 ; 0.18 ; 0.30 ; and $0.39 \mathrm{~g} \mathrm{~kg}^{-1}$ of the nutrient in the soil. The phosphorus fertilization was done at the time of sowing by the incorporation of nutrients in the soil. The fertilization with the other required nutrients was proceeded in three parcels, at 15, 25, and 35 days after sowing.

\section{Water management}

For the levels of water availability, the level of $80 \%$ of available water (AW) was used as standard irrigation for crambe; this amount was based on preliminary observations with this species. The irrigation were managed to allow the AW to be depleted to $80 \%, 50 \%$, and $25 \%$ of the total AW, as levels of water availability. The irrigation was performed when the soil moisture reached the levels corresponding to each treatment, returning the water level back to the reference level.

The plants were kept in these conditions from 15 to 45 days after emergence through daily monitoring of the moisture in the pots. The procedures to determine the irrigation levels followed the methodology described by Bernardo et al. (2008), which required the hydro-physical analysis of the soil to obtain the required parameters. The hydro-physical analysis was performed according to the methodology proposed by Embrapa (1997) (Table 1).

\section{Cultivation and evaluations}

The seeds of Crambe abyssinica Hochst, cultivar FMS Brilhante, were provided by the MS Foundation and were sown in plastic pots $(14 \mathrm{~L}$ of volume). Five seeds were sown per pot, and, after emergence, thinning was performed to allow the growth of only one plant per pot. 
Table 1. Hydro-physical attributes of the soil used in the experiment.

\begin{tabular}{lccccccc}
\hline \multicolumn{2}{l}{ Granulometric analyses } & \multirow{2}{*}{$\mathrm{Sd}^{(1)}$} & $\mathrm{Pd}^{(2)}$ & $\mathrm{P}^{(3)}$ & $\mathrm{FC}^{(4)}$ & $\mathrm{PWP}^{(5)}$ \\
\hline Sand & Silt & Clay & & & & & \\
\hline & $\%$ & & \multicolumn{2}{c}{$\mathrm{kg} \mathrm{dm}^{-3}$} & $\mathrm{~m}^{-3} \mathrm{~m}^{-3}$ & & $\%$ \\
\hline 49.10 & 5.30 & 45.60 & 1.10 & 2.71 & 0.592 & 28.80 & 13.57 \\
\hline
\end{tabular}

(1) $\mathrm{Sd}=$ Soil density; (2) $\mathrm{Pd}=$ Particles density; (3) $\mathrm{P}=$ Porosity; (4) $\mathrm{FC}=$ Proportion of soil humidity in the field capacity (tension: $0.01 \mathrm{Mpa}$ ); (5) $\mathrm{PWP}=$ Proportion of soil humidity in the permanent wilting point (tension: $1.50 \mathrm{Mpa}$ ).

The plants were cultivated for 45 days to gather information on their vegetative growth patterns, from emergency to flowering. After, the plant materials (leaves, stems, and roots) were collected and separated in paper bags, which were then dried in an oven, with forced air circulation at $60.0^{\circ} \mathrm{C}$, until constant weight. After drying, the plant materials were weighed on an analytical balance (precision: $0.0001 \mathrm{~g}$ ) and triturated to obtain a homogeneous powder.

The material was weighed on an analytical balance, resulting in the values of grams per plant to determine the mass of dry matter of shoots (DMS) and the dry matter of roots (DMR). The DMS representing the sum of the weight of the dry mass of leaves, stems, and branches. The total dry matter (TDM) was obtained by the sum of the DMS and the DMR.

The concentration of phosphorus in the plant tissues was evaluated using the methodology described by Defelipo e Ribeiro (1996). The total phosphorus content was calculated based on the phosphorus concentration and biomass of each plant.

Utilizing the dry matter and the content of nutrients in the vegetal tissues, the following indices were calculated: (a) Absorption efficiency (ABE), according to Swiader et al. (1994); (b) Translocation efficiency (TRE), according to Li et al. (1991); and (c) Use efficiency (USE), according to Siddiqi and Glass (1981).

\section{Data analysis}

The collected data were subjected to analysis of variance and, according to the presence of significant differences, the means of the levels of available water were studied using the Tukey test (5\% of probability), and the means of the levels of phosphorus fertilization were studied using regression analysis (5\% of probability). The analyses were performed using the statistical software SISVAR (Ferreira, 2011).

\section{Results}

\section{Biomass allocation and nutritional parameters of plants of crambe modulated by water availability}

The availability of water in the soil strongly influenced the patterns of biomass allocation in plants of crambe when subjected to different levels of phosphorus fertilization. By analyzing the production of DMS, it is noticeable that the higher mean values at the level of $80 \%$ of AW, while the lowest production occurred when the plants were subjected to lower levels of available water, independently of the supply of $\mathrm{P}$ (Table 2).

For the production of DMR, it is clear that, at the lowest level of P, there was the formation of smaller root systems with the lowest water availability and larger root biomass being observed with higher water availability. However, the production of DMR was statistically similar between AW levels at a dose of $0.18 \mathrm{~g}$ of $\mathrm{P}_{2} \mathrm{O}_{5}$ per $\mathrm{kg}$ of soil. At a level of $0.30 \mathrm{~g}$ of $\mathrm{P}$, the higher production of root mass occurred at the lowest level of AW in the soil. With the addition of $0.39 \mathrm{~g}$ of $\mathrm{P}_{2} \mathrm{O}_{5}$, the highest production occurred at the level of $80 \%$ of AW. The root biomass allocation patterns from the dose of $0.18 \mathrm{~g}$ of $\mathrm{P}_{2} \mathrm{O}_{5}$ draw attention, possibly due to the low water availability and increasing supply of $\mathrm{P}$, the plants of crambe focused the metabolism on increasing the root mass in order to better explore the soil in the search for water (Table 2).

However, when it comes to the production of TDM, it appears that the higher level of water availability favored higher biomass production at all levels of phosphorus supply, which is similar to that observed for the SDM (Table 2). 
Table 2. Means of dry matter of shoots (DMS), dry matter of roots (DMR) and total dry matter (TDM) of crambe plants, depending on levels of available water (AW) in the soils for each level of phosphorus fertilization.

\begin{tabular}{lcrrrr}
\hline \multirow{2}{*}{ Variable } & AW $(\%)$ & \multicolumn{4}{c}{ Level of $\mathrm{P}_{2} \mathrm{O}_{5}\left(\mathrm{~g} \mathrm{~kg}^{-1}\right)$} \\
\cline { 3 - 6 } & & 0.06 & 0.18 & 0.30 & 0.39 \\
\hline \multirow{3}{*}{ DMS (g) } & 80 & $9.20 \mathrm{a}$ & $12.44 \mathrm{a}$ & $14.19 \mathrm{a}$ & $16.77 \mathrm{a}$ \\
& 50 & $7.98 \mathrm{~b}$ & $7.95 \mathrm{~b}$ & $11.35 \mathrm{~b}$ & $11.77 \mathrm{~b}$ \\
& 25 & $6.93 \mathrm{c}$ & $7.40 \mathrm{~b}$ & $10.52 \mathrm{c}$ & $10.02 \mathrm{c}$ \\
\hline \multirow{2}{*}{ DMR (g) } & 80 & $1.11 \mathrm{a}$ & $1.46 \mathrm{a}$ & $2.04 \mathrm{~b}$ & $3.23 \mathrm{a}$ \\
& 50 & $0.88 \mathrm{~b}$ & $1.32 \mathrm{a}$ & $2.13 \mathrm{~b}$ & $2.59 \mathrm{~b}$ \\
& 25 & $0.45 \mathrm{c}$ & $1.33 \mathrm{a}$ & $2.41 \mathrm{a}$ & $2.61 \mathrm{~b}$ \\
\hline \multirow{2}{*}{ TDM $(\mathrm{g})$} & 80 & $10.32 \mathrm{a}$ & $13.90 \mathrm{a}$ & $16.23 \mathrm{a}$ & $20.00 \mathrm{a}$ \\
& 50 & $8.86 \mathrm{~b}$ & $9.27 \mathrm{~b}$ & $13.49 \mathrm{~b}$ & $14.36 \mathrm{~b}$ \\
& 25 & $7.39 \mathrm{c}$ & $8.73 \mathrm{~b}$ & $12.93 \mathrm{~b}$ & $12.64 \mathrm{c}$ \\
\hline
\end{tabular}

Means followed by the same lowercase letter in the column, for each variable, do not differ by Tukey test $(\mathrm{p} \leq 0.05)$.

The water availability has served as conditioning of the ability of crambe plants to accumulate P. In the lower level of $\mathrm{P}$ used in the study; there was no difference in the content of $\mathrm{P}$ in terms of AW levels. At a level of $0.18 \mathrm{~g}$ of $\mathrm{P}_{2} \mathrm{O}_{5}$, the highest accumulation was due to increased water availability in the soil, while there was no difference between the levels of $50 \%$ and $25 \%$ of AW. At 0.30 and 0.39 g of $\mathrm{P}_{2} \mathrm{O}_{5}$ per kg of soil, the plants of crambe showed higher $P$ content with the greater availability of water; the lowest content with the lower availability of water, and intermediate value in the condition of $50 \%$ of AW (Table 3). This shows that compared to the conditions of the same fertilization with phosphorus, the crambe plants are able to absorb and accumulate this nutrient in different levels depending on the

Table 3. Content of phosphorus in the total dry matter (TPC), absorption efficiency (ABE), translocation efficiency (TRE) and use efficiency

(USE) of phosphorus in crambe plants, depending on the available water (AW) in the soil, for each level of phosphorus fertilization.

\begin{tabular}{lccccc}
\hline \multirow{2}{*}{ Variable } & AW $(\%)$ & \multicolumn{4}{c}{ Level of $\mathrm{P}_{2} \mathrm{O}_{5}\left(\mathrm{~g} \mathrm{~kg}^{-1}\right)$} \\
\cline { 3 - 6 } & & 0.06 & 0.18 & 0.30 & 0.39 \\
\hline \multirow{2}{*}{ TPC $(\mathrm{mg})$} & 80 & $29.66 \mathrm{a}$ & $62.14 \mathrm{a}$ & $90.95 \mathrm{a}$ & $153.57 \mathrm{a}$ \\
& 50 & $29.94 \mathrm{a}$ & $42.10 \mathrm{~b}$ & $68.79 \mathrm{~b}$ & $100.63 \mathrm{~b}$ \\
& 25 & $22.64 \mathrm{a}$ & $37.16 \mathrm{~b}$ & $58.94 \mathrm{c}$ & $75.16 \mathrm{c}$ \\
\hline \multirow{2}{*}{$\mathrm{ABE}\left(\mathrm{mg} \mathrm{g}^{-1}\right)$} & 80 & $26.59 \mathrm{c}$ & $42.44 \mathrm{a}$ & $44.49 \mathrm{a}$ & $47.51 \mathrm{a}$ \\
& 50 & $33.89 \mathrm{~b}$ & $31.89 \mathrm{~b}$ & $32.18 \mathrm{~b}$ & $38.86 \mathrm{~b}$ \\
& 25 & $49.49 \mathrm{a}$ & $27.96 \mathrm{~b}$ & $24.46 \mathrm{c}$ & $28.78 \mathrm{c}$ \\
\hline \multirow{2}{*}{ TRE $(\%)$} & 80 & $90.58 \mathrm{c}$ & $92.01 \mathrm{a}$ & $90.40 \mathrm{a}$ & $88.84 \mathrm{a}$ \\
& 50 & $94.85 \mathrm{~b}$ & $90.90 \mathrm{ab}$ & $87.62 \mathrm{~b}$ & $87.81 \mathrm{a}$ \\
& 25 & $96.50 \mathrm{a}$ & $90.00 \mathrm{~b}$ & $84.40 \mathrm{c}$ & $83.11 \mathrm{~b}$ \\
\hline & 80 & $3.59 \mathrm{a}$ & $3.12 \mathrm{a}$ & $2.90 \mathrm{a}$ & $2.61 \mathrm{a}$ \\
USE $\left(\mathrm{g}^{2} \mathrm{mg}^{-1}\right)$ & 50 & $2.63 \mathrm{~b}$ & $2.04 \mathrm{~b}$ & $2.65 \mathrm{a}$ & $2.05 \mathrm{~b}$ \\
& 25 & $2.42 \mathrm{~b}$ & $2.05 \mathrm{~b}$ & $2.84 \mathrm{a}$ & $2.13 \mathrm{~b}$ \\
\hline
\end{tabular}

Means followed by the same lowercase letter in the column, for each variable, do not differ by Tukey test $(\mathrm{p} \leq 0.05)$. 
water availability in the soil, where a higher water supply favors the accumulation of $\mathrm{P}$.

Regarding the $\mathrm{ABE}$, it is noticed that, at the dose of $0.06 \mathrm{~g}$ of $\mathrm{P}_{2} \mathrm{O}_{5}$, the higher ABE was obtained at $25 \%$ of $\mathrm{AW}$, and the lowest at the level of $80 \%$. At a dose of $0.18 \mathrm{~g}$, the level of $80 \%$ of AW provided the highest absorption efficiency, whereas, at levels of $50 \%$ and $25 \%$, the ABE has lower. At doses of 0.30 and $0.39 \mathrm{~g}$ of $\mathrm{P}_{2} \mathrm{O}_{5}$ and a level of $80 \%$ of $\mathrm{AW}$, the highest values of $\mathrm{ABE}$ were obtained. The level of $25 \%$ of AW caused the worst results for the absorption efficiency (Table 3).

Analyzing the TRE in crambe plants, it is noted that at the dose of $0.06 \mathrm{~g}$ and level of $80 \%$ of AW, the TRE was lower; while the $25 \%$ of AW favored higher TRE. At a dose of $0.18 \mathrm{~g}$ of $\mathrm{P}_{2} \mathrm{O}_{5}$, the level of $80 \%$ of AW favored the development of the efficiency, while the growth at $25 \%$ of AW caused lower TRE. At the level of 50\% of AW, the TRE was similar to the levels of $80 \%$ and $25 \%$ of AW. For the addition of $0.30 \mathrm{~g}$ in the fertilization, the TRE was higher at the level of $80 \%$ of AW, and lower the level of $25 \%$. In the dose of $0.39 \mathrm{~g}$, higher TRE was obtained at $50 \%$ and $80 \%$ of AW (Table 3).

By analyzing the USE, it is clear that at doses of $0.06,0.18$, and $0.39 \mathrm{~g}$ of $\mathrm{P}_{2} \mathrm{O}_{5}$, the level of $80 \%$ of AW promoted the greatest USE in crambe plants. On all other levels, the USE was smaller, and there was no statistical difference in the results between them. At a dose of $0.30 \mathrm{~g}$, there was no difference between the USE values as a function of AW levels, showing that at this dose, the plants developed the same ability to utilize the nutrient for the production of biomass (Table 3).

\section{Biomass allocation and nutritional parameters of plants of crambe modulated by phosphorus supply}

For all the parameters discussed above, it was observed that there was a significant effect, at 5\% probability, by regression analysis of the level of $\mathrm{P}_{2} \mathrm{O}_{5}$ added in the fertilization, as a function of each of the levels of AW.

For the parameters DMS, DMR and TDM, the data presented fit the linear model of $1^{\text {st }}$ degree, with the characteristics increasing due to the increase in the $\mathrm{P}$ supply (Figure 1A, 1B and 1C).

For the production of DMS, the levels of AW affected the responsiveness to the fertilization, namely the level of $80 \%$ of AW gave a more
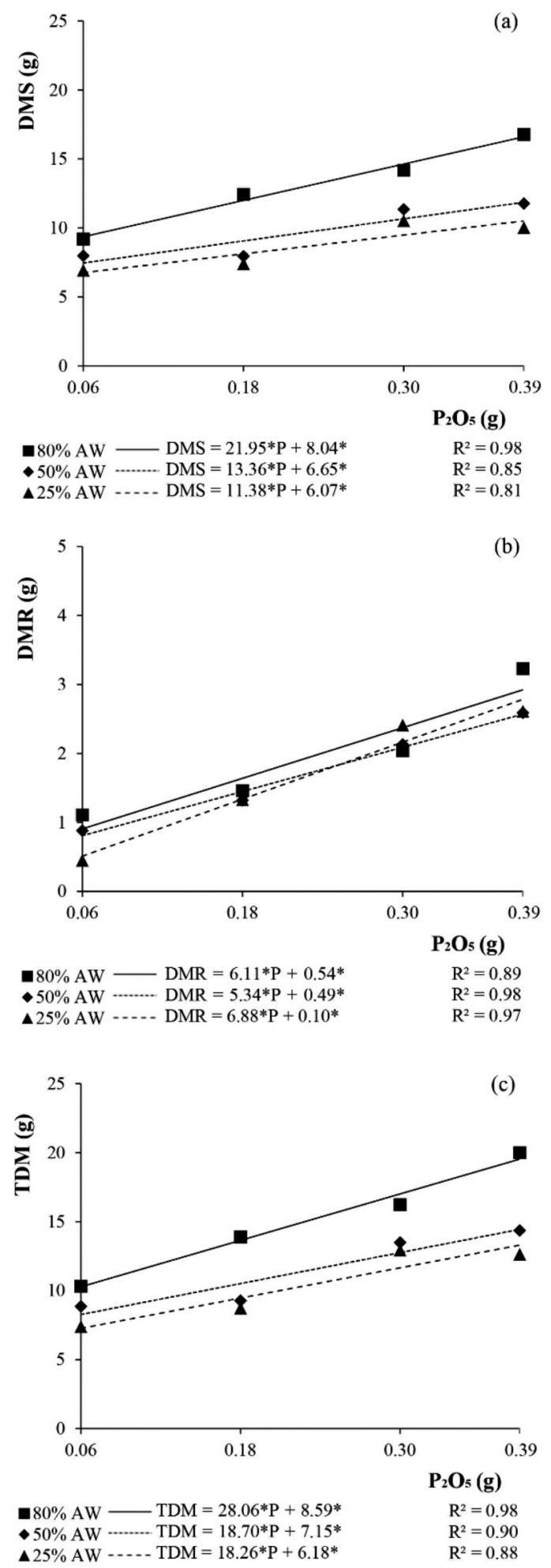

Figure 1. Regression analysis for dry matter of shoots (a), dry matter of roots (b) and total dry matter (c) of crambe plants, as function of the phosphorus fertilization, for each level of water availability in the soil. 
pronounced response, confirmed by the greater slope of the regression (21.95). With $25 \%$ of AW, the response of plants was less expressive, where plants subjected to this condition had the lowest DMS as a function of phosphorus fertilization, confirmed by the smaller slope (11.38) (Figure 1A). Figure 1C shows that the response of plants in the production of TDM followed a similar behavior to DMS, which expresses the relationship between these two variables since one is dependent upon another.

For DMR, it is observed that the level of $80 \%$ of AW rendered the best results. However, it is clear that there was a tendency for better results in the production of root biomass at the level of $25 \%$ of AW than at the level of 50\%, above the dose of $0.25 \mathrm{~g}$ of $\mathrm{P}_{2} \mathrm{O}_{5}$.
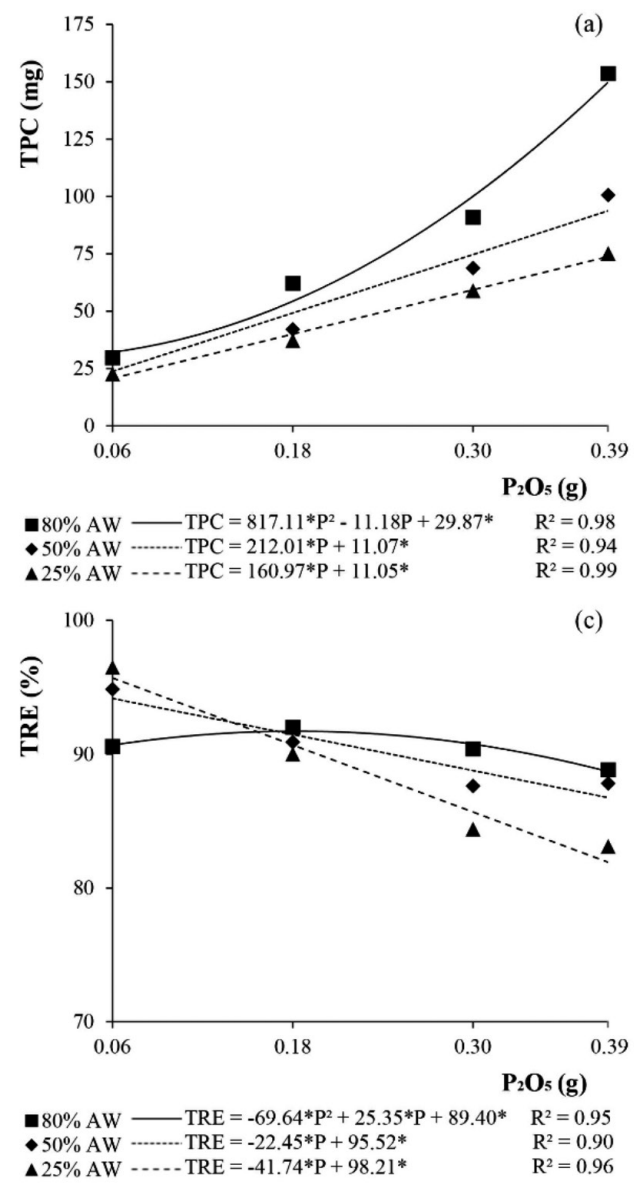

Analyzing the content of phosphorus in the total dry matter (TPC) of crambe plants, it is perceived a fit to linear regression model of $2^{\text {nd }}$ degree at the level of $80 \%$ of AW in the soil. In comparison, the increase of phosphorus supply for levels 50\% and 25\% was adjusted to linear models of $1^{\text {st }}$ degree, which indicates a proportional increase in the content of $\mathrm{P}$ in the biomass due to the increase of $\mathrm{P}_{2} \mathrm{O}_{5}$ levels in the soil. The curves start from close values of TPC (at $0.06 \mathrm{~g}$ of $\mathrm{P}_{2} \mathrm{O}_{5}$ per $\mathrm{kg}$ of soil). However, it is remarkable that as the dosage increases, and with a higher level of AW, the accumulation of $\mathrm{P}$ is greater in the tissues of the crambe plants, which has a direct effect on metabolic processes and the growth and development of plants, presenting smaller risk of deficiency of that nutrient in their tissues (Figure 2).

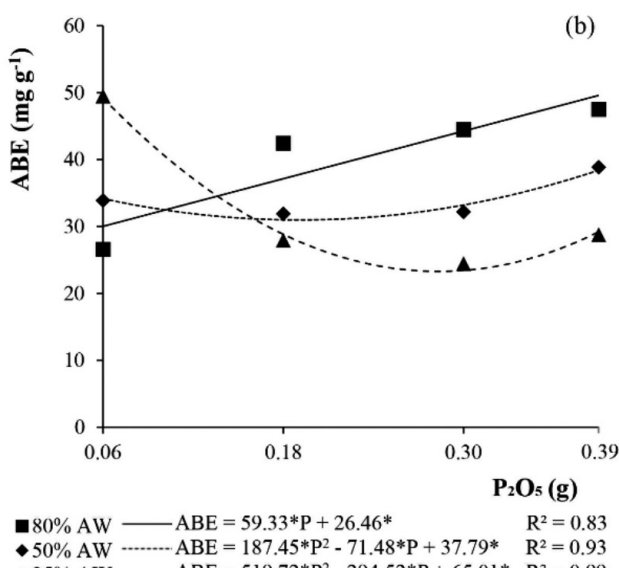

$\triangle 25 \%$ AW - - . ABE $=519.72 * \mathrm{P}^{2}-294.52 * \mathrm{P}+65.01 * \mathrm{R}^{2}=0.99$

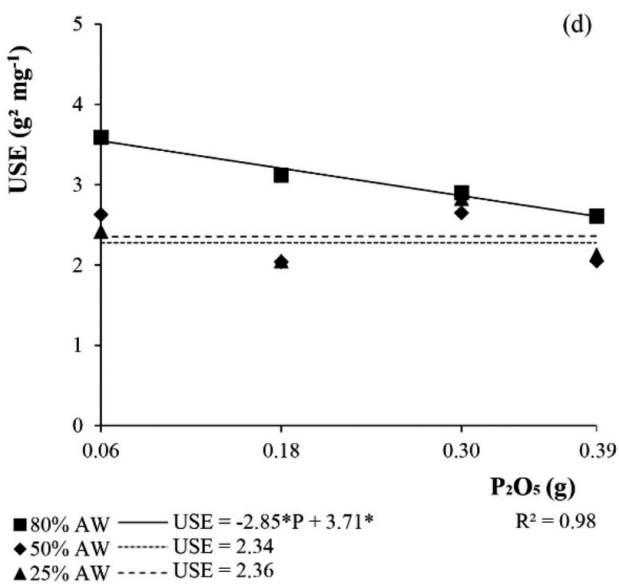

Figure 2. Regression analysis for total phosphorus content (a), absorption efficiency of phosphorus (b), translocation efficiency of phosphorus (c) and use efficiency of phosphorus (d) of crambe plants, as function of the phosphorus fertilization, for each level of water availability in the soil. 
As shown in Figure 2C, the ABE presented fit to a crescent linear model of $1^{\text {st }}$ degree at the level of $80 \%$ of AW, as a function of increased $\mathrm{P}$ levels in the soil, or in that increased dosage of said nutrient in the fertilization, causing a proportional increase in the absorption by the plant. At $50 \%$ of AW, the adjust is given by the linear model of $2^{\text {nd }}$ degree, presenting quadratic behavior with a minimum point, where the lower $\mathrm{ABE}$ occurred at a dose of $0.19 \mathrm{~g}$ of $\mathrm{P}_{2} \mathrm{O}_{5}$, presenting a slight increase from that point. At the level of $25 \%$ of $\mathrm{AW}$, the behavior was also quadratic with minimum point, however, the inflection of the curve was steeper than the observed at level of 50\%. With $25 \%$ of $\mathrm{AW}$, it is noticed that increasing the dosage of $\mathrm{P}_{2} \mathrm{O}_{5}$ caused a reduction in the $\mathrm{ABE}$ to the dose of $0.28 \mathrm{~g}$, presenting a slight increase over this level (Figure 2C). However, it can be said that the level of $80 \%$ of AW provided the best results regarding the $\mathrm{ABE}$, due to trend of linear growth (Figure 2C). Moreover, higher production of biomass was obtained at the level $80 \%$ of AW (Figure 1), showing the relationship between growth and nutritional efficiency (Figure 2).

As for TRE, it notes that in the level of $25 \%$ of $\mathrm{AW}$, there was a linear decrease in response to the increasing level of fertilization (linear model of $1^{\text {st }}$ grade). This same behavior is seen at the level of $50 \%$ of AW; however, it is noteworthy that the reduction is less pronounced in this condition than at the level of 25\% of AW (Figure 2D). Analyzing the level of $80 \%$, a quadratic behavior was noticed, with maximum point for TRE at $0.18 \mathrm{~g}$ of $\mathrm{P}_{2} \mathrm{O}_{5}$ (Figure 2D).

Figure 2B shows the behavior of the crambe plants in response to the fertilization with $\mathrm{P}$. The use efficiency of phosphorus decreased with the phosphorus fertilization at level of $80 \%$, showing adjustment to a $1^{\text {st }}$ degree model, while for conditions of $50 \%$ and $25 \%$, no changes in the use efficiency were observed, indicating that the plants probably absorbed and used the nutrient in similar ratios. However, it is noteworthy that although decreasing, the answers in USE obtained at the level of $80 \%$ of AW were still all higher than those found in other AW levels. This demonstrates that in this level of water supply, crambe plants produce larger quantity of biomass per unit of absorbed $\mathrm{P}$ when compared to the other two levels of AW, which is a consistent response to the highest content of $\mathrm{P}$ and higher biomass obtained at this level of AW.
As shown in Figure 2B, the addition of $0.06 \mathrm{~g}$ of $\mathrm{P}_{2} \mathrm{O}_{5}$ promoted the highest USE, which leads to the inference that the plants were more efficient in use the nutrient. For the other dosages, the reduction in the use efficiency probably occurred because the crambe plants absorbed phosphorus in higher proportion than used it in biomass production, possibly, with higher nutrient availability, the plant absorbed and stored $\mathrm{P}$ for use throughout its cycle, especially in the stages of flowering and grain filling. It is known that the crambe presents great demand for this nutrient, whereas $\mathrm{P}$ is the most prominent element in the development of these plants (Colodetti et al., 2013).

Comprehensively, there is a strong interaction between water availability and the phosphorus fertilization to determine the nutritional efficiency in crambe plants (Table 2; Figure 2). Regarding the efficiency parameters addressed in the study, it is perceivable the adaptive response of crambe plants towards the induced stressful situations (hydric and nutritional).

\section{Discussion}

The reduction in biomass production by plants of crambe as function of the decreasing levels of AW occurred due to the deleterious effects that water stress may cause in plants, since the water stress causes a reduction in cell turgor, which causes reduction in the growth rate of the plant. Furthermore, higher severities of water stress cause the inhibition of photosynthesis, by dehydration of the leaf mesophyll cells, the metabolism in the mesophyll is impaired and the efficiency of use of the water reduces dramatically (Taiz and Zeiger, 2013). Thus, the plant pause or reduces sharply the photosynthetic activity, which compromises metabolism and consecutively biomass production.

In crambe cultivation, the water supply is predominant for the growth and development of plants, since the biomass production may increase with the higher water supplementation (up to 2.5 times of reposition of evaporated water) (Butrinowski et al., 2011; Santos et al., 2012). In cultivations such as canola, it has also been observed positive correlations between rainfall and higher seed yield, being also observed that water stress during flowering acts negatively on the formation of pods and seed size (Delkhosh et al., 2012). That is, both for crambe and other cultures, water is essential for obtaining better 
growth rates, development and crop yield, especially when associated with the adequate mineral nutrition.

The production of root mass increased with the reduction of AW. Perhaps this growth behavior of the root system under such stressful conditions has occurred due to a strategic role to contour the water stress, by producing more root mass and less shoot mass in order to better exploit the soil it occupies. However, this trend is observed only after an initial increase in the fertilization with phosphorus, an element that is essential for root development. According to Roscoe et al. (2010), crambe has an aggressive root system, capable of satisfactorily tolerate periods of drought.

Besides acting on the growth and development of the crambe plants, phosphorus is also considered the most limiting nutrient to the accumulation of dry matter of such plants (Colodetti et al., 2013), it is known that fertilization with this nutrient is also capable of benefit grain and oil yield (Rogério et al., 2013). Furthermore, it has been found that the growth of crambe was favored by fertilization with phosphorus and adequate availability of water in the soil (Colodetti et al., 2015).

Regarding the accumulation of $\mathrm{P}$, the increase content of $\mathrm{P}$ by crambe at all levels of fertilization with this nutrient, was only possible due to the effects of increased availability of water in the soil, since the diffusion of $\mathrm{P}$ to the roots is fundamentally dependent on soil moisture (Ruiz et al., 1988).

The results obtained in the lower level of fertilization make possible to affirm that, as function of the increased water restriction, crambe becomes more efficient in absorbing P, since the content of this nutrient was statistically similar in relation to those obtained at higher water supply in the soil, but with a biomass root much smaller, that is, even with less roots, the plants were able to absorb $\mathrm{P}$ in the same proportion. This hypothesis is consistent when analyzed together with the methodology of Swiader et al., (1994), where the absorption efficiency of a given nutrient is taken as the ratio of the total content of nutrient in the plant and the dry mass of roots. Possibly, this was due to a physiological strategy of crambe plants to stay alive and be able to perpetuate the species, becoming more efficient to absorb nutrients in the most limiting condition employed by the study.

The TRE is linked to the proportion of the nutrient that is allocated in the DMS in relation to the allocation in the DMR ( $\mathrm{Li}$ et al., 1991), ie, the lowest level of AW in the soil (25\%) was able to promote the highest TRE at the lowest level of fertilization with $\mathrm{P}$, which may be explained by the higher $\mathrm{ABE}$ in function to the smaller root system, since, in such conditions, the crambe plants produced fewer roots, and yet was able to accumulate the same $\mathrm{P}$ content that for the others levels of water supply, which resulted in higher ABE and TRE. As the level of fertilization with $\mathrm{P}$ increased, this behavior was reversed.

The capacity of the plant has to absorb, accumulate, translocate and use phosphorus are dependent on several factors and interactions, where soil moisture is characterized as one major factor (Baligar and Fageria, 1999).

The presence of water in the soil is highly correlated with the availability of phosphorus for plants, particularly on soils with a high degree of weathering, such as Brazilian soils. In such conditions, the process of diffusive transport of phosphorus to the roots is very limited and the degree of adsorption of $\mathrm{P}$ in the colloidal particles that generate electric charges is very sharp; causing the phosphorus availability in these soils to became very small (Novais et al., 2007). It is in this context, the water plays a fundamental role, as the soil moisture increases, the layer of water surrounding the colloidal particles becomes thicker, reducing the ion-colloid interaction. As a result of the decreased tortuosity and the viscosity of water, the impedance factor increases, due to the greater distance between the ions and colloids of soil, contributing greatly to increase the process of phosphorus diffusion in the soil solution to the plant roots. This direct relationship between the soil water content and phosphorus diffusion has been widely reported (Remer and Schilling, 1981; Ruiz, 1986; Costa et al., 2006; Novais et al., 2007). The results found in this study are largely anchored in this context, since the important role of water to achieve better use of the fertilization with $\mathrm{P}$, expressed in the production of biomass, contents of $\mathrm{P}$ and variables of nutritional efficiency.

The physic nut is another promising oilseed for biodiesel production, for which the effect of phosphorus was already studied, already being reported that higher phosphorus fertilization provided greater accumulation of this nutrient in the plant tissues (Amaral et al., 2012). It is known that the identification of promising genetic material that present good accumulation of $\mathrm{P}$ tends to also exhibit a positive correlation with characteristics 
and development of mechanisms responsible for the optimization of translocation efficiency of this nutrient (Machado et al., 2004).

A study involving ten genotypes of another oilseed species (physic nut) and two levels of P supply in the soil showed that, in general, the absorption, translocation and use efficiency of phosphorus was lower due to higher availability of $\mathrm{P}$ in the soil (Amaral et al., 2012), which corroborates with the behavior observed for crambe with the greater availability of water in the soil and increasing doses of phosphorus.

\section{Conclusions}

Increasing the phosphorus supply in the soil promotes a higher biomass production in crambe plants, which is more pronounced when it is combined with increased availability of water.

The increase in water availability and phosphorus fertilization levels near the recommended level promotes higher nutritional efficiencies in absorbing, translocating, and using the phosphorus available in the soil.

\section{Literature cited}

Amaral, J.F.T.; Martins, L.D.; Laviola, B.G.; Christo, L.F.; Tomaz, M.A.; Rodrigues, W.N

2012. A differential response of physic nut genotypes regarding phosphorus absorption and utilization is evidenced by a comprehensive nutrition efficiency analysis. Journal of Agricultural Science. 4: 164-173.

Baligar, V.C.; Fageria, N.K.

1999. Plant nutrient efficiency: Towards the second paradigm. In: Siqueira, J.O.; Moreira, F.M.S.; Lopes, A.S.; Guilherme, L.R.G.; Faquin, V.; Furtini Neto, A.E.; Carvalho, J.G. Interrelação Fertilidade do solo, biologia do solo e nutrição de plantas. SBCS. Lavras, Brazil. pp. 183-204.

Bajehbaj, A.A.; Qasimov, N.; Yarnia, M.

2009. Effects of drought stress and potassium on some of the physiological and morphological traits of sunflower (Helianthus annuus L.) cultivars. Journal of Food Agriculture and Environment. 7: 448-451.

Bernardo, A.; Soares, A.A.; Mantovani, E.C. 2008. Manual de irrigação. 8th ed. UFV. Viçosa, Brazil. 625 p. Butrinowski, I.T.; Santos, R.F.; Maggi, M.F.; Borsoi, A.; Frigo, E.P.; Bassegio, D.

2011. Manejo da irrigação com mini-tanque evaporímetro em Crambe abyssinica. Revista Cultivando o Saber. 4(3): 54-65.

Colodetti, T.V.; Tomaz, M.A.; Rodrigues, W.N.; Reis, E.F.; Pizetta, S.C.; Brinate, S.V.B.; Christo, L.F.; Martins, L.D.; Amaral, J.F.T.

2015. Phosphorus fertilization and water management as prevalent factors in the growth of Crambe abyssinica. American-Eurasian Journal of Agricultural \& Environmental Sciences. 15(4): 581-587.

Colodetti, T.V.; Martins, L.D.; Rodrigues, W.N.; Brinate, S.V.B.; Tomaz, M.A.

2012. Crambe: Aspectos Gerais da Produção Agrícola. Enciclopédia biosfera. 8: 258-269.

Colodetti, T.V.; Rodrigues, W.N.; Christo, L.F.; Martins, L.D.; Tomaz, M.A.

2013. Perda de biomassa causada pela deficiência de macronutrientes em Crambe abyssinica. Enciclopédia biosfera. 9: 2027-2038.

Costa, J.P.V.; Barros, N.F.; Albuquerque, A.W.; Moura Filho,

G.; Santos, J.R.

2006. Influence of phosphorus doses and soil moisture on diffusion flow. Revista Brasileira de Engenharia Agrícola e Ambiental. 10(4): 828-835.
Defelipo, B.V.; Ribeiro, A.C.

1996. Análise química do solo: metodologia. VImprensa Universitária. Viçosa, Brazil. 17 p.

Delkhosh, B.; Rad, A.H.S.; Bitarafan, Z.; Mousavi Nejad, G. 2012. Drought stress and sowing date effects on yield and some grain traits of Rapeseed. Advances in Environmental Biology. 6(1): 49-55.

Embrapa.

1997. Empresa Brasileira de Pesquisa Agropecuária. Manual de métodos de análises de solo. 2nd ed. Ministério da Agricultura e do Abastecimento. Rio de Janeiro, Brazil. 212 p.

Ferreira, D.F.

2011. Sisvar: A computer statistical analysis system. Ciência e Agrotecnologia. 35: 1039-1042.

Li, B.; McKeand, S.E.; Allen, H.L.

1991. Genetic variation in nitrogen use efficiency of loblolly pine seedlings. Forest Science. 37(2): 613-626.

Machado, C.T.T.; Furlani, A.C.; Machado, A.T.

2004. Índices de eficiência de variedades locais e melhoradas de milho ao fósforo. Bragantia. 60(3): 225-238.

Novais, R.F.; Neves, J.C.L.; Barros, N.F.

1991. Ensaio em ambiente controlado. In: Oliveira, A.J.; Garrido, W.E.; Araújo, J.D.; Lourenço, S. (ed) Métodos de pesquisa em fertilidade do solo. Embrapa/SAE. Brasília, Brazil. pp. 189-254.

Novais, R.F.; Smyth, T.J.; Nunes, F.N.

2007. Phosphorus. In: Novais, R.F.; Alvarez, V.H.V.; Barros, N.F.; Fontes, R.L.F.; Cantarutti, R.B.; Neves, J.C.L. (ed) Soil fertility. Sociedade Brasileira de Ciências do Solo. Viçosa, Brazil. pp. 276-374.

Remer, W.; Schilling, G.

1981. Effect of the soil water regime on the diffusion coefficient of phosphate ions. Soviet Soil Science. 13: 110-114.

Rogério, F.; Silva, T.R.B.; Santos, J.I.; Poletine, J.P.

2013. Phosphorus fertilization influences grain yield and oil content in crambe. Industrial Crops and Products. 41: 266-268.

Roscoe, R.; Pitol, C.; Broch, D.L.

2010. Necessidades climáticas e ciclo cultural. In: Pitol, C.; Broch, D.L.; Roscoe, R. (ed) Tecnologia e produção: crambe 2010. Fundação MS. Maracajú, Brazil. pp. 7-9.

Ruiz, H.A.

1986. The transport of phosphorus in the soil solution. Revista Cultura. 36: 65-72. 
Ruiz, H.A.; Fernandes, B.; Novais, R.F.; Alvarez V, V.H.1 988. Efeito da umidade do solo sobre o volume e conteúdo de fósforo no exsudato xilemático de soja. Revista Brasileira de Ciências do Solo. 12(1): 39-42.

Santos, R.F.; Fornasari, C.H.; Secco, D.; Souza, S.N.M.; Silva, T.R.B.; Bassegio, D.

2012. Manejo de irrigação com evaporímetro em Crambe abyssinica. Acta Iguazu. 1(1): 23-32.

Siddiqi, M.Y.; Glass, A.D.M.

1981. Utilization index: a modified approach to the estimation and comparison of nutrient utilization efficiency in plants. Journal of Plant Nutrition. 4(3): 289-302.

Siqueira, O.J.W.; Steinmetz, S.; Ferreira, M.F.; Costa, A.C.; Wozniak, M.A.

2010. Mudanças climáticas projetadas através dos modelos GIS e reflexos na produção agrícola brasileira. Revista Brasileira de Agrometeorologia. 8(2): 311-320.
Silva, C.A.T.; Cagol, A.; Silva, T.R.B.; Nóbrega, L.H.P.

2011. Boron application before sowing of sunflower hybrids. Journal of Food Agriculture and Environment. 9: $580-583$.

Souza, A.D.V.; Fávaro, S.P.; Ítavo, L.C.; Roscoe, R.

2009. Caracterização química de sementes e tortas de pinhãomanso, nabo-forrageiro e crambe. Pesquisa Agropecuária Brasileira. 44(10): 1328-1335.

Swiader, J.M.; Chyan, Y.; Freiji, F.G.

1994. Genotypic differences in nitrate uptake and utilization efficiency in pumpkin hybrids. Journal of Plant Nutrition. 17(10): 1687-1699.

Taiz, L.; Zeiger, E.

2013. Fisiologia vegetal. 5th ed. Artmed. Porto Alegre, Brazil. 918 p. 